\title{
Child-Naming Customs among the Yakima Indians ${ }^{1}$
}

\author{
THELMA E. WEEKS
}

NLY a LITTLE MORE THAN 100 years ago the Yakima Indians freely wandered the montains and streams of the Northwest, hunting and fishing, root-digging and berry-picking in season, each completely content with just one name - his individual Indian name. Then in 1858 they were moved onto the Yakima Indian Reservation in the state of Washington, and were required by the United States government to have two names: a first name, which shall be referred to in this paper as the given name, and a last name, which shall be referred to here as the surname. In addition to these two names, which are required for the English-speaking community, the Yakimas of today who tend to follow the old customs of their people also have a Yakima Indian name, just they have always had, for the Indian-speaking community. This Indian name shall be referred to in this paper as the personal name.

The response to the requirement of the government for two names was met by different Indian tribes in different ways. In some parts of the United States the Indians took surnames similar to those of the nonIndian people in the area - English, French, or Spanish-sounding names, according to the part of the country in which they lived. The Yakimas, however, chose to use their own Indian names as surnames. In some instances these Indian names were translated into English; examples are Halfmoon, Fox, Weasle Tail, and Cloud. More often, however, the names were transliterated into English orthography. Many names became unrecognizable in this process because the Yakima language (called Yakima by the Indians, but called Sahaptin by linguists) has so many sounds that English does not have, particularly guttural sounds, such as glottalized velar and palatal consonants. Indian surnames currently in use on the Reservation such as Sohappy and Miller, are not translated names, but are the original Indian names as rendered by some government employee writing the Indian name as he heard it spoken, and trying his best to fit the Yakima name into the Roman alphabet. The Yakima name

1 The Yakima Indian Reservation is in central Washington, about 100 miles north of the Oregon boundary. There are approximately 3,500 Yakimas on the reservation now, about 1,500 of them speaking Sahaptin, their native Indian language. Of these Sahaptin speakers, a great many still cling to one form or another of their traditional Indian religion. Although they are not isolated as the Indians of the Southwest are, there has been comparatively little intermarriage with non-Indians. 
Mlamu became Lumley, for example. Poor transliteration has caused the meaning of some names to be completely lost to present day Yakimas.

The given names of the Yakima Indians today are Christian names such as Robert or Stanley, which are given to babies at birth without ceremony, just as in the English-speaking community. These two names - the Christian given name and the former personal Indian name which is now the family surname - are used exclusively in the English-speaking community and in dealing with the government.

However, many of the Yakimas have been reluctant to give up many aspects of the old Indian culture, and having a personal Indian name (in addition to the two names discussed above) is one of the customs they cling to. They also continue to conduct their ancient ceremonies of formal name-giving.

In time past the Yakimas gave their children temporary Indian names at birth, without ceremony. These names were used in the Indian community until the formal naming took place. ${ }^{2}$ This is not practiced on the Reservation today. If a baby is called by name, the English given name is used. However, family members usually address each other by kin terms (e.g., núka "younger brother") during their entire lifetime, rather than by name.

One three-year-old girl, whose given name was Ona, said, when asked what her name was, that it was úćau. Her mother said that this was a name she had made up for herself and that she always referred to herself by it. It sounds like a Yakima word: čáu means "no" or "not," but účau has no apparent meaning. Perhaps she was impatient to be given her Indian name, or perhaps her Yakima-speaking grandmother, who lived with her and took care of her, had shouted "čáu!" at her so often she thought it was part of her name!

The parents decide at what age a child shall be given his personal name. In the past, as now, this has usually been when the child is about four years old, but it can be any time from about six months up to about 12 years of age. One young Yakima woman, a follower of their traditional Indian religion, recently said, "It's not good to give the children their names too young. I have known babies who died because God was angry that the parents named them too young."

Most Northwest Indian tribes have traditionally believed that a child was born with the spirit of some deceased loved one, therefore naming the child after that person. The Yakima Indians have always had this belief, and in present times the personal name given to a child is almost always one that belonged to a deceased member of the family. Although in current practice a child's name usually turns out to be the name of a

${ }^{2}$ Edward Curtis, The North American Indian, vol. 7 (Norwood, Mass. 1911), p. 9. 
grandparent or great-grandparent, in theory, as with many other Northwest Indian tribes, the name is supposed to be the name of the person whose role the child can be expected to fulfill, for he will be greeted as that person come back to life. The spirit of a deceased chief, for example, would be expected to be found only in the body of a child who had the attributes of a leader. For this reason, the older a child is, the easier it is to select the most appropriate name for him. If a boy is being given the name of a chief or a very distinguished member of the tribe, as a rule it will not be given to him until he is about 12, the age of maturity in Indian tribes.

In writing about the Yakimas at an earlier time, Andrew Splawn ${ }^{3}$ says that the child was frequently named after his father (but not while he was living) or after a plant, animal, bird, or some physical phenomenon occurring at the time of birth. For example, many years ago a Yakima chief was named k'at'a tlku'sm "half sun" because a partial eclipse of the sun occurred at his birth. At the present time, however, at the formal namegiving ceremony only names of deceased relatives seem to be given to children.

Here are a few Yakima names which might be given to children: kúsinut "horseless" (kúsi = horse); kiyiya "howling wolf" ( $y a=$ personifier as used in myths; tiskái = "skunk," the animal, tiskayái = "skunk" as a person); kaymúxnit "spotted fawn" (a woman's name); yúkuš "deer horn"; či $i$ miša "sinew bow"; yumtíbi "bitten by a grizzly bear" (a Yakima chief who died in 1910); luláwqan "hat band"; and hwistaks "dress that swishes" (a woman's name).

Some Yakimas report that they do not know the meaning of their Indian (personal) name. Some of the names were borrowed from neighboring languages as a result of intertribal marriages which were very common in years past as well as now. The meanings of some words have been lost to native speakers just as the meanings of some archaic English words are lost to new generations, perhaps more so among the Yakimas, however, since theirs is an unwritten language.

Yet, the giving of original names is still extant in the Yakima Nation. Original names - new personal names - are often given to adults as a result of special events or accomplishments. For example, yumti bi "bitten by a grizzly bear" and wi ? áxa.s "one without big toe" both tell of a circumstance in the life of a person. If a man gains a reputation as being quite a "ladies' man," or if he does something extraordinarily well, such as riding horses in rodeo events, he may be given a name to reflect this. This name could be changed several times in his adult life. Each time he gains a new personal name, he drops the old one. This second or third

\footnotetext{
${ }^{3}$ Andrew Splawn, Ka-mi-akin, The Last Hero of the Yakimas (Portland, Oregon, 1917), p. 399.
} 
personal name, if it lasts long enough to be well established, may be passed on to the children of another generation. However, if a man has been given the name of a prominent ancestor, such as a chief or a talented shaman (medicine man), in the formal naming ceremony as a child, he will probably not allow any other name to take its place, though it might serve as a temporary nickname.

\section{Name-Giving Ceremonies}

The name-giving ceremonies of the Yakima Indians (the giving of the personal, or Indian name) were once held in the home, with friends and relatives invited for a feast. Someone chosen by the parents gave a speech endowing the child with his new name and asking the blessings of the spirits upon the child. ${ }^{4}$ In recent years the name-giving ceremonies on the Yakima Reservation have usually been held in the longhouses, most often in conjunction with some other celebration on the Reservation as a matter of convenience in getting people together. Some friends and family members who live on the Umatilla Reservation or the Warm Springs Reservation (both in Oregon and both Sahaptin-speaking tribes) make a practice of attending each other's celebrations. Sometimes they drive this distance (150 to 200 miles) just for a child-naming ceremony and the accompanying feast.

One of the important aspects of the name-giving ceremony is the giving of gifts to those attending the ceremony, and of lesser importance, the giving of gifts to the child who receives the name. The child's family gathers together an assortment of personal items for gifts, some newly made, such as beaded moccasins, ceremonial costumes, baskets, or anything the craftsmen in the family can make, and some items which have been treasured in the family for some time, such as any of the items just mentioned, hunting knives, or anything for personal use. All of the people who talked to me seemed to feel that the gifts should consist of some new and some old items - that it would not be appropriate to have only new items.

Before the ceremony starts, the gifts to be given to the guests are laid out on display at the front of the room so that they surround the child during the ceremony. After his name has been given to him at the conclusion of a speech and supplication to the spirits, members of the family and their friends go to the child, shake his hand, greet him by his new name, and welcome back the spirit of the person whose name he is taking. Though it is not required (as is the giving of gifts to the guests) guests often bring a gift to the child. In present times the gift is often money. The gifts are not intended to be suitable to the age of the child; rather,

4 Curtis, loc. cit. 
they are supposed to be something that will be useful in his adulthood, such as the gifts the child's parents are giving to the guests. After greeting the child a guest may choose for himself a gift from among those displayed. However, there will probably not be as many gifts as there are guests, and people are expected to take only an item for which they have a need.

As might be implied from this description, the name-giving ceremony is also something of a memorial service for the deceased relative (Memorial Day is a popular time for name-giving ceremonies), for the deceased person's friends and relatives have not been allowed to speak his name for the first five years following his death. ${ }^{5}$ None of my Yakima informants could (or would) offer a reason for not speaking the name of the deceased person for this period of time, but the Papago Indians observe a similar custom except that the name of the dead person is never mentioned at all after his death for fear that the ghost, thinking itself called, might come and take some loved one for companionship. ${ }^{6}$ The Yakimas need not have this fear, of course, once the spirit has been given an earthly dwelling place in a child.

\section{Conclusions}

The Yakima Indians who continue the custom of giving Indian names to their children in formal ceremonies are generally those who are very proud of their heritage and wish to cling to as many aspects of their Indian culture as they can. Most of these people remain on the Indian reservation as a matter of choice, rather than moving to the cities to find new jobs and take on a new culture. These are the same Indians who place great value on other Indian ceremonies, feasts, dances, and traditional Indian celebrations. The Indian name (or personal name) is an integral part of all of this.

\section{Stanford University}

5 This time period is determined by the length of time it takes bones to "crumble" for the spirit to be completely free of the body.

6 Ruth Underhill, Red Man's America (Chicago, 1953) p. 193. 